\title{
Narın (Punica granatum L.) İnsan Sağlığına Etkileri
}

\author{
Mikdat ŞiMŞEK ${ }^{1}$, Ali íkinci2* \\ ${ }^{1}$ Dicle Üniversitesi, Ziraat Fakültesi, Bahçe Bitkileri Bölümü, Diyarbakır \\ [ORCID: https://orcid.org/0000-0002-6108-088X] \\ ${ }^{2}$ Harran Üniversitesi, Ziraat Fakültesi, Bahçe Bitkileri Bölümü, Şanlıurfa \\ [ORCID: https://orcid.org/0000-0001-8149-7095] \\ *Sorumlu yazar: aliikinci@harran.edu.tr
}

\begin{abstract}
Öz
Tropik ve subtropik meyve olarak bilinen narın (Punica granatum L.), zengin besin değeri ve insan sağlğı üzerindeki olumlu etkilerinden dolayı günümüzde önemi giderek artmaktadır. Nar; eski çağlardan beri bilinmekte, taze olarak tüketilebildiği gibi, meyve suyuna, meyve suyu konsantresine, reçele, şaraba ve liköre işlenebilen, çeşitli gıdalara renk verici ve tatlandırıcı olarak katılan ve içerdiği biyoaktif bileşenler sayesinde yüzyıllardan beri halk arasında uygulanan geleneksel tedavi yöntemlerinde kullanılan bir meyvedir. Bu bağlamda, uzun yıllar süren bilimsel çalışmalar, narın insan vücudunu pozitif olarak etkileyen besin içerikleri ile yüklenmiş olduğunu ortaya çıkarmıştır. Bu makale nar tüketiminin ve içerdiği antioksidant maddelerin insan sağlığına faydaları konusunda yapılan bilimsel çalışma sonuçlarının derlenmesini amaçlamaktadır.
\end{abstract}

Anahtar Kelimeler: Nar, Beslenme, Antioksidant aktivite, İnsan sağlığı

\section{Effects of Pomegranate (Punica granatum L.) on Human Health}

\begin{abstract}
As a tropic and subtropic fruit, nowadays pomegranate (Punica granatum L.) has been of great importance due to its nutrient content and positive effects on human health. This fruit has been known since ancient times. As it can be freshly consumed, it has been processed into juice, fruit juice concentrate, jam, wine, and liqueur. This fruit has also widely been used as an ingredient for coloring and sweetness in various foods. It has also been used as a folk medicine due to its rich content of bioactive compounds. In this context, long years of scientific studies revealed that pomegranate is full of rich nutrients positively effects on the human body. The aim of this study is the compilation of scientific study results carried out regarding the antioxidant content of pomegranate and the benefits of the pomegranate consumption for human health.
\end{abstract}

Key Words: Pomegranate, Nutrition, Antioxidant activity, Human health

\section{Giriş}

Günümüzde bilim ve teknolojinin daha hızlı gelişmesiyle, insanlar sağlıklı yaşamaya ve insan sağlığı açısından faydalı gıdalar tüketmeye daha fazla özen göstermeye başlamışlardır. Bu bağlamda, meyve türlerine verilen değer gittikçe önem kazanmış ve renkli meyve ve sebzelerin yanı sıra tohumları tüketilen bitkilerin önemi artmıştır. Örneğin; nar, ayva, fındık, kiraz, erik, antepfıstığı, vişne, badem, elma, armut, ceviz, kestane ve incir gibi meyvelerin yetiştiriciliğine 
büyük önem verilmektedir (Şimşek ve Gülsoy, 2017). Bu meyve türleri içerisinde nar, dünyada popülaritesi en çok artan meyveler arasında bulunmaktadır (Durgaç ve ark., 2008).

Subtropik ve tropik iklime sahip Akdeniz ülkelerinin önemli meyve türlerinden olan nar'ın (Punica granatum L.) (Öz ve ark., 2015) kültür tarihi oldukça eskilere uzanmakta olup, yetiştiricilik geçmişinin M.Ö. 3000 yıl öncesine kadar dayandığı belirtilmektedir (Gerçekçioğlu ve ark., 2014; Şimşek ve Kara 2016). Bu meyve türü Afganistan, Fas, Filistin, Irak, İran, Kıbrıs, Mısır, Suriye, Suudi Arabistan, Tunus, Türkiye, Hindistan, $A B D$, Çin, İspanya, İsrail, İtalya ve Tayland başta olmak üzere, dünyanın birçok ülkesinde yetiştirilmektedir (Gündoğdu ve Yılmaz, 2013). Dolayısıyla, kültüre alınan en eski tarım ürünlerinden olan nar bitkisi, insanlık tarihinde önemli bir konuma sahiptir. Ülkemiz, nar üretimi bakımından önemli bir konumda olup, 2015 yılı verilerine göre, 52 ilde nar üretimi yapılmakta ve bunlar arasında 10000 ton'un üzerinde üretim gerçekleştiren 7 il bulunmaktadır. Bu iller arasında Antalya (107 237 ton) birinci sırada yer alırken, Mersin (61 919 ton) ikinci, Denizli (45 594 ton) üçüncü, Adana (39 715 ton) dördüncü, Hatay (20 769 ton) beşinci, Gaziantep (19 370 ton) altıncı ve İmir (11 854 ton) ise yedinci sırada yer almaktadır. Nar üretimi yapan illerimiz arasında Batman 439 ton ile son sırada yer almaktadır (TÜiK, 2015).

Bilim ve teknolojinin gelişmesiyle, iletişim de insanlar arasında daha hızlı yaygınlaşmaya başlamış, bu vesile ile hem narın ve hem de birçok meyve türünün insan sağlığına olan etkileri daha iyi anlaşılmış ve bu yüzden, gün geçtikçe nar ve öteki meyvelerin tüketimi önem kazanmaya başlanmıştır (Şimşek ve Gülsoy, 2016). Ayrıca, son yıllarda yetiştirme tekniği, gıda teknolojisi, depolama ve taşıma alanlarında görülen gelişmelerden dolayı nar ve birçok meyve türü daha çok tanınmaya ve yetiştiriciliklerine daha fazla önem verilmeye başlanmıştır. Avrupa ülkelerinin nar meyvesine olan talebi gün geçtikçe artmakta olup, Arap ülkeleri de bu meyveye büyük ilgi göstermektedir (Özgüven ve Yılmaz, 2000; Vardin, 2000; İkinci ve Kılıç, 2016). Ülkemizin pek çok yöresi nar yetiştiriciliğine uygun olduğundan dolayı, bu ülkeler başta olmak üzere, diğer ülkelere de nar satışı yapılabilir.

Insanlar narı daha çok taze olarak tüketmektedirler. Bunun yanı sıra, ilaç ve boya yapımında, nar pekmezi ve nar ekşisi, meyve suyu ve konservesi, sirke, sitrik asit, hayvan yemi, çekirdeklerinden bitkisel yağ üretimi, çeşitli içkilerde ferahlatıcı bir katkı maddesi olarak değerlendirilmesinin yanı sıra, çeşitli endüstri kollarında da değerlendirilebilmektedir (Mavlyanov ve ark., 1997; Gündoğdu ve ark., 2011; İkinci ve Kılıç, 2016).

Narın meyve suyunda SÇKM'nin \%13.3-16.9, pH'nın 0.93-4.6 ve titre edilebilir asitliğin \% 0.25-3.17 arasında değiştiği (Mars ve Marrakchi, 1999), Hicaznar çeşidinin şırasında sakkaroz, glikoz ve fruktoz olmak üzere toplam 3 
adet şeker bulunduğu ve bunların toplam miktarının $125.74 \mathrm{~g} \mathrm{~L}^{-1}$ olduğu, bunlar arasında en fazla fruktoz $\left(63.85 \mathrm{~g} \mathrm{~L}^{-1}\right)$ bulunduğu, bunu sırasıyla glikoz (58.13 g $\left.\mathrm{L}^{-1}\right)$ ve sakkaroz' un $\left(3.76 \mathrm{~g} \mathrm{~L}^{-1}\right)$ takip ettiği (Kelebek ve Canbaş, 2010), bazı nar çeşit ve tiplerine ait meyve sularındaki $N^{\prime}$ un 111.57-1007.33 ppm, P'un 215.98-338.35 ppm, K'un 547.15-1651.30 ppm, Ca'un 21.91-69.81 ppm, Fe'in 2.52-5.38 ppm, Mn'ın 0.150-0.649 ppm, Zn'nun 0.4131.201 ppm, Cu'ın 0.253-2.388 ppm ve Mg'un 26.76-128.40 ppm arasında değiştiği saptanmıştır (Gündoğdu ve Yılmaz, 2013).

Birçok biyokimyasal madde bakımından oldukça zengin olan narın insan sağlığı açısından önemi oldukça büyüktür. Bu bağlamda, bu meyve türü kansere karşı koruyuculuk sağlama, kalp ve damar hastalıklarııı tedavisi (Tezcan ve ark., 2009) ve kolesterol ile şeker düzeyinin dengelenmesi (Öz ve ark., 2015) başta olmak üzere, insan sağlığı üzerine birçok etkisi mevcuttur. Nar; folik asit, potasyum, fosfor, demir, C vitamini ve lif yönünden bir hayli zengindir (Şekil 1). Antioksidan içeriği yeşil çaydan üç kat fazla olan nar, hücre yenilenmesini büyümesini ve bağışılık sistemini kuvvetlendirerek, vücut direncini artırmaya yardımcı olur. Antioksidan özelliği ile kansere karşı koruyucudur.

Bu nedenle, bu meyve türü ile ilgili yapılan her bir çalışmanın özellikle organik nar yetiştiriciliğinin (Şimşek ve Yücel, 2015) yaygınlaşmasına, ülkemizin ekonomisine ve daha sağlıklı birey ve toplumun oluşmasına katkıda bulunacağı düşünülmektedir.

\section{Narın İnsan Sağlığına Etkileri Konusunda Yapılan Bazı Çalışmalar}

"Nar Meyve Kabuklarıın Eczacilık Yönünden Değerlendirilmesi" adlı çalışmada, narın meyve kabuğunun hem eczacılık hem de diğer alanlarda proantosiyanidin ve kersetol kaynağı olarak değerlendirilebildiği ifade edilmiştir (Özkal ve Dinç, 1993).

"Narın Farmakolojik ve Terapötik Özellikleri" adlı çalışmada, nardaki flavanoidlerin güçlü bir antioksidan oldukları, nar meyve suyu ve yağının ömrün uzamasının yanı sıra, kalp hastalıkları ve kanserin önlenmesine sebep olduğu, günümüzde AIDS için kullanılan yiyecekler sınıfına alındığı ve Japon patentli ilaçlarda bulunan 9 bitkiden biri olduğu belirtilmiştir (Lansky ve ark., 1998).

"Nar Suyu Tüketimi Oksidatif Stresi Azaltır, LLD Üzerine Aterojenik Değişiklikler ve Trombosit Toplanması" adlı araştırmada, nar suyunun; tüketimini izleyen bir yıllık sürenin sonunda nar'ın sitolik kan basıncını önemli ölçüde azalttığı tespit edilmiştir. Ayrıca; ellajik asit, insan sağlığı üzerindeki olumlu etkilerinden dolayı nar meyvesindeki en önemli biyoaktif bileşen olduğu, antioksidan, antikanserojenik, antiöstrojenik ve antimutajenik etkilerinin bulunduğu bildirilmektedir (Aviram ve ark., 2000) 


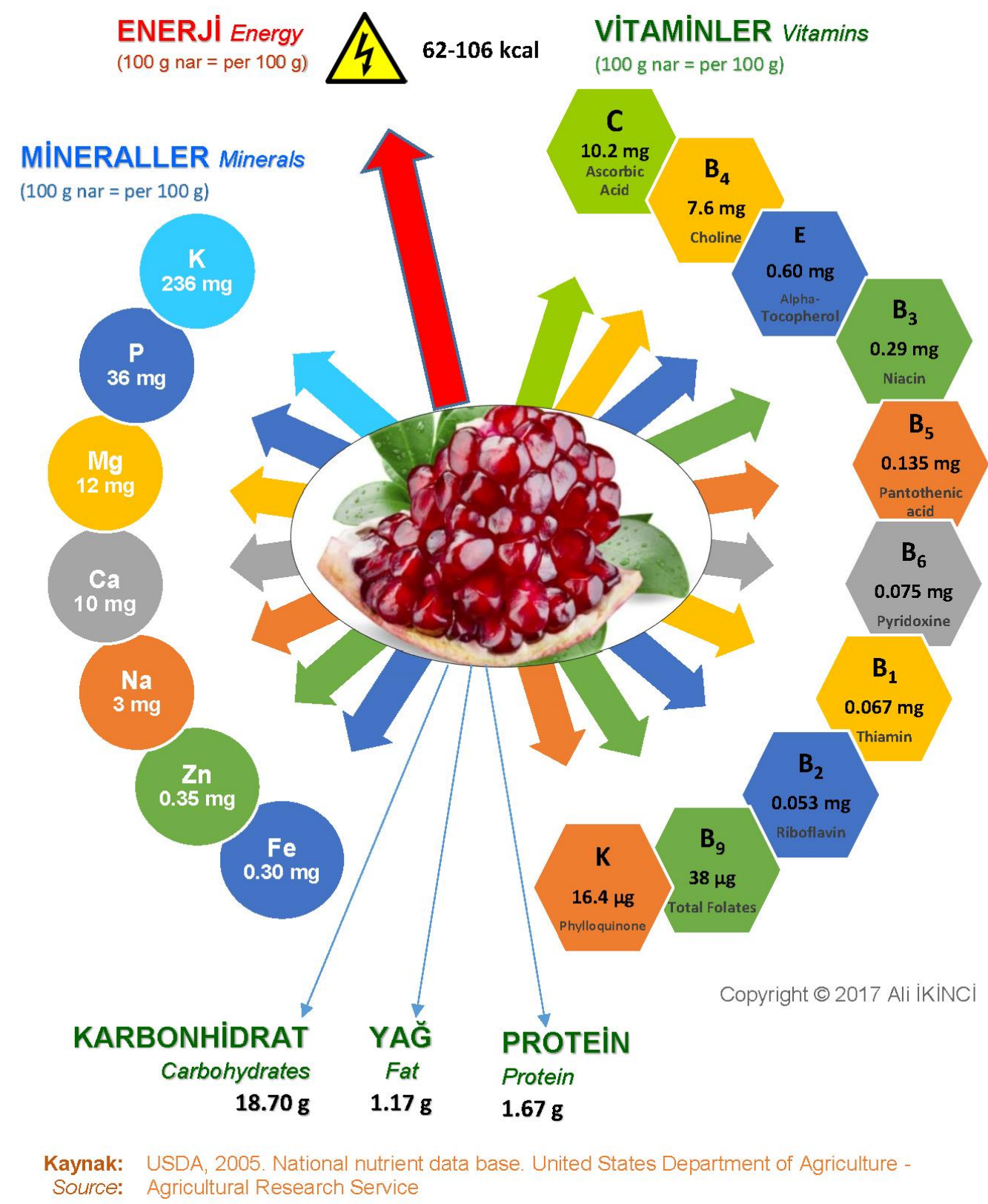

Şekil 1. Nar meyvesinin besin içeriği (100 g danede)

Figures 1. Nutritional composition of the pomegranate (Values per 100 gram of edible portion)

"Nar suyunun antioksidan aktivitesi, fenolik bileşimi ve işlenmesi arasındaki ilişkisi" adlı makalede, narın ve nar suyu konsantresinin ticari değerini belirleyen en önemli kriterin yapısında doğal olarak bulunan monomerik antosiyanin içeriğinden kaynaklandığı ifade edilmiştir.
Renk maddesi olarak gıdalara çekici bir renk kazandırmasının yanı sıra, gösterdikleri antioksidan etki nedeniyle antosiyaninlerin birçok kronik hastalığı önleyici etkiye sahip olduğu belirtilmektedir (Gil ve ark., 2000). 
"Doğal bir fenolik antioksidan olan ellagic asit üzerine çalışmaları" adlı araştırmada, ellajik asidin serbest radikallere bağlanarak, oksidatif zararlanmalara ve bunların sebep olduğu bazı kanser tipleri gibi hastalıklara karşı organizmayı koruduğu belirtilmektedir (Priyadarsini ve ark., 2002).

"Prostat kanserinin kemotedavisi ve kemoterapisi için nar suyu" adlı çalışmada, nar suyunun damar üzerindeki zararı engellediği, prostat kanseri ve kireçlemeyi önlediği belirtilmiştir (Malik ve ark., 2005).

"Gıdalarda bulunan doğal koruyucular" adlı çalışmada, antioksidanların, özellikle farmakolojik çalışmalarda önem kazandığından dolayı, nardaki antioksidanların gün geçtikçe daha fazla önem kazandığı, nar suyunun ishali durdurabildiği, otooksidasyon zararlarına karşı hücreleri koruyabildiği, kandaki glikoz seviyesini muhafaza edebildiği, hücrelerin birbirleriyle iletişimini sağlayan protein ve peptidlerin bir kısmının oluşmasına katkı sağladığı ve kemik eklemi iltihabını önleyebildiği ifade edilmektedir (Coşkun, 2006).

"Nar: Bileşimi ve insan sağlığı üzerindeki etkileri" adlı çalışmada, narın taze olarak tüketilebildiği gibi, meyve suyuna, meyve suyu konsantresine, reçele, şaraba ve liköre işlenebildiği, çeşitli gıdalara renk verici ve tatlandırıcı olarak katıldığı ve biyoaktif bileşenlerinden dolayı yüzyıllardan beri geleneksel tedavide kullanılan bir meyve olduğu belirtilmektedir (Tamer, 2006).

"Çeşitli ekstraksiyon koşullarının nar tohum yağının fenolik içerikleri üzerine etkisi" adlı çalışmada, narın çiçeğinden meyve kabuğuna, meyve suyundan posasına, konserveli içeceklerinden jel ve marmelatına ve hatta pasta ve diyet ekmeği yapımına kadar her türlü ürünün değerlendirilmesinde kullanılan bir meyve olduğu belirtilmiştir (Abbasi ve ark., 2007).

"Nar suyu konsantresi üretim ve depolama süresince antioksidan aktivitedeki değişimler" adlı çalışmada, nar suyunun endüstriyel üretiminde, presleme boyunca kabuk ve bölmeler arası dokulardan meyve suyuna yüksek miktarda fenolik bileşik geçtiğini, elde edilen nar sularının antioksidan aktivitesinin önemli bölümünün, hidrolize olabilen ellajitanenler ve gallotanenler denilen fenoliklerden, siyanidin ve delfinidin denilen antosiyaninlerden, kuersetin, kamferol ve luteolin glikozitler denilen diğer flavonoid bileşiklerden ve ellajik asitten kaynaklandığı saptanmıştır. Fenolik bileşiklerin sahip olduğu antimikrobiyel ve antioksidan aktiviteden dolayı, onları gıdaların muhafazasında etkili kılmakta ve sağlık endişelerine neden olan sentetik gıda katkı maddelerine alternatif doğal bileşikler haline de getirmektedir. İşte bu nedenlerden dolayı fenolik bileşiklerce çok zengin bir meyve olan nara ve bu üründen elde edilen meyve sularına olan ilgi artmıştır (Apaydın, 2008).

"Gıdalardaki polifenoller Alzheimer hastalığına meydan okuyor" adlı çalışmada, özellikle son yıllarda nardaki biyoaktif bileşenlerin insan sağlığına etkilerinin anlaşılmasından sonra çok popüler bir meyve konumuna gelmiş 
olup, hem ülkemizde hem de tüm dünyada nara ve nardan üretilmiş ürünlere çok ciddi bir talep artışı olmuştur. Bu bağlamda, kliniksel bulgularda nar suyunun insan kanındaki parametrelerinde olumlu değişikliklere neden olduğu, kanı sıvılaştırdığı, kötü huylu kolesterolü düşürdüğü, özel bir prostat antijenini arttırdığı, antioksidan aktivitesi çok yüksek polifenollere sahip olması nedeniyle Alzheimer ve kalp rahatsızlıklarının tedavisine yardımcı olduğu ve bazı kanser hastalıklarına karşı vucuda dirençlik sağladığı belirtilmektedir (Singh ve ark., 2008).

"Altı Nar (Punica granatum L.) Çeşidinin Antimikrobiyal Aktivitesi ile Bunların Bazı Pomolojik ve Fitokimyasal Özellikleriyle ilişkisi" adlı çalışmada, Akdeniz Bölgesi'nde yetişmekte olan altı nar (Punica granatum L.) çeşidinin dane ekstraksiyonlarının antimikrobiyal özellikleri incelenmiş ve yedi bakteri (Bacillus megaterium DSM 32, Pseudomonas aeruginosa DSM 9027, Staphylococcus aureus Cowan 1, Corynebacterium xerosis UC 9165, Escherichia coli DM, Enterococcus faecalis A10, Micrococcus luteus LA 2971 ve üç fungusa (Kluvyeromyces marxianus A230, Rhodotorula rubra MC12, Candida albicans ATCC 1023) karşı test edilmiştir. Nar dane ekstraksiyonlarının tüm mikroorganizmalara karşı antimikrobiyal etki gösterdikleri gözlemlenmiştir. Elde edilen sonuçlar Punica granatum çeşitlerinin antimikrobiyal potansiyellerini doğrulamaktadır. (Duman ve ark., 2008). Bu nedenle nar tüketiminin insan sağlığı üzerinde özellikle bazı hastalık etmenlerinin gelişimini engellemede oldukça önemli etkilere neden olabileceği düşünülmektedir

"Nar suyu üretim teknolojisi üzerine araştırmalar" adlı çalışmada, narın meyve olarak en önemli olumsuzluğu, çoğu kez iri bir çekirdek etrafında küçük bir meyve suyu keseciğinin bulunması nedeniyle, meyve suyunu tüketebilmek için bu çekirdeğin de çiğnenmesinin zorunlu olmasıdır. $\mathrm{Bu}$ nedenle, bu meyveyi tüketebilmenin en iyi yolu, meyve suyuna işlenmesidir. Ancak, meyve suyunun doğal halinde bile 2000 $\mathrm{mg} \mathrm{L}^{-1}$ gibi yüksek düzeyde fenolik madde içerdiği belirtilmektedir (Cemeroğlu, 1977). Cemeroğlu (2009), "Meyve ve Sebze işleme Teknolojisi" adlı kitabında, nar suyunda fenolik madde fazlalığından kaynaklanan bu olumsuzluğu önlemenin yolunun, preslemede aşırı basınç uygulamasından kaçınmak gerektiği şeklinde belirtmiştir. Meyve suyu randımanının; meyve çeşidine, kullanılan pres tipine ve uygulanan pres basıncına göre değiştiği ifade edilmektedir (Cemeroğlu, 2009).

"Türkiye'de yetiştirilen 10 nar çeşidinin meyve suyunun karakterizasyonu" adlı çalışmada, nar suyunun önemli bir antioksidan gıda olduğu ve bu özelliğinin sebebi ise içeriğindeki fenol bileşiklerden kaynaklandığı belirtilmektedir. Fenol bileşiklerin ise antioksidan etkileri nedeniyle serbest radikalleri bağlamaları, metallerle şelat oluşturmaları ve bazı enzimleri inaktive etmelerinden dolayı insan sağlığı üzerinde oldukça önemli 
etkilere neden olduğu belirtilmektedir (Çam ve ark., 2009).

"Nar suyu kimyasal bileşimi ve kılavuz değerleri" adlı çalışmada, ülkemizde yetiştirilen narların bileşiminde bulunup tat ve aroma bakımından bazı önemli bileşiklerin şekerler ve organik asitler olduğu belirtilmektedir. Çalışmada; sitrik asit, malik asit, okzalik asit ve askorbik asit'in narda bulunan önemli organik asitler olduğu vurgulanmıştır. Ayrıca, nar suyu bileşiminde glikoz, fruktoz ve sakkaroz bulunmakta olup, glikoz/fruktoz'dan elde edilen değer yardımıyla nar sularına yapılan hileler kontrol edilebilmektedir (Ekşi ve Özhamamcı, 2009).

"Şirvan (Siirt) yöresinde yetiştirilen narların pomolojik özellikleri" adlı çalışmada, narın vücudu ve kalbi kuvvetlendirdiği, ishali, kabızlığı, öksürüğü, mide yanmaları ve kusmayı kesebildiği, vücuttaki bazı ağrıları giderebildiği, şerit düşürmede etkili olduğu, idrar söktürebildiği, boğaz, göğüs, akciğer ve mideye oldukça yararlı olduğu, tansiyon ve ateş düşürücü etkiye sahip olduğu ve damar tıkanıklığını önleyici etkiye sahip olduğundan dolayı yüzyıllardan beri halk hekimliğinde değerlendirildiği belirtilmiştir. Ayrıca; antimikrobiyal, antiparasitik, antiviral ve antikanserojen gibi özelliklerinin belirlenmesi nedeniyle, yakın gelecekte bu meyveye olan ilginin daha da artacağı ifade edilmiştir (Gündoğdu ve ark., 2010).

"Nar kabuğu, kurusu, mezokarpı ve farklı bir şekilde üretilen suyunun fenolik bileşiklerinin tanımlanması ve miktarının belirlenmesi" adlı çalışmada, nar meyvesinin içilebilir kısmını oluşturan meyve suyunun yanı sıra kabuğu, kurusu ve çekirdeklerinde onlarca fenolik bileşeni barındırdığı, bu bileşenlerin meyve suyuna ciddi miktarda geçebildiği ve bunlar arasında punicalagin'in en yüksek antioksidan aktiviteye sahip olduğu bildirilmiştir (Fischer ve ark., 2011).

"Nar suyu konsantresi üretiminde uygulanan bazı işlemlerin fenolik bileşenler üzerine etkisi" adlı çalışmada, nar suyundaki fenolik bileşiklerin gösterdikleri antioksidan etki sebebiyle, aralarında kalp ve damar hastalıkları, kanser ve şeker hastalıklarının da bulunduğu pek çok ciddi ve yaygın hastalığı önleyici etki gösterdiği ve yaşlanmayı geciktirdiği belirtilmektedir (Karaca, 2011).

"Güneydoğu Anadolu Bölgesi'nde nar üretimi ve pazarlanması" başlıklı çalışmada, nar üzerine yapılan birçok tıbbi çalışmalarda antioksidan içeriğinin yüksekliğinin yanı sıra kanı sıvılaştırdığı, kötü huylu kolesterolü düşürdüğü, Alzheimer ve kalp rahatsızlıklarının tedavisinde etkili olduğu, bazı kanser türlerine karşı vücuda direnç sağladığı, nar suyunun kandaki parametrelerde olumlu değişikliklere sebep olduğu belirtilmiştir (Oğuz ve ark., 2011).

"Türkiye'de nar tarımı ile ilgili bir ziraat coğrafyası" adlı makalede, narın kanser başta olmak üzere, sağlık açısından faydaları sebebiyle bütün dünyada gerek yaş meyve olarak gerekse nar suyu olarak tüketiminin yaygınlaştığı belirtilmektedir. Bu bağlamda, insan sağlığına olan faydaları sebebiyle adeta 
bir ilaç, hatta antibiyotik olarak görev yaptığı, özellikle bağışıklık sistemini güçlendirerek pek çok hastalıktan koruduğu, içerdiği bazı maddeler nedeniyle kolesterol ve şekeri dengelediği, kalp sağlığını koruduğu, cilt ve prostat kanserine karşı koruyucu etkisinin olduğu belirtilmiştir (Kurt ve Şahin, 2013).

"Akdeniz Bölgesi'nde yetiştirilen bazı nar çeşit ve genotiplerin fenolik bileşenleri ve antioksidan aktivitelerinin belirlenmesi" adlı çalışmada, narın kalp ve damar hastalıklarında tedavi edici mineraller ve anti-aterosklerotik fonksiyonel etkiye sahip bileşikler içerdiği ve sindirim sistemine yararlı olduğu belirtilmektedir. Ayrıca, narın başka faydalarının da bulunduğunu belirtilerek, bu meyvenin üretimi ve tüketiminde önemli artışlar yaşandığı vurgulanmıştır (Turgut ve Seydim, 2013).

"Nar (Punica granatum L.) çeşit ve genotiplerin fizikokimyasal karakterizasyonu" adlı çalışmada, narın genel olarak vücudu ve kalbi kuvvetlendirdiği, ishali, öksürüğü, kabızlığı, mide yanmalarını ve kusmayı kestiği, vücuttaki bazı ağrıları giderilebildiği, şerit düşürdüğü, idrarı söktürdüğü, boğaz, göğüs, akciğer ve mideye olumlu etki ettiği, tansiyon düşürdüğü, ateşli hastalıkların ateşini düşürdüğü ve damar tıkanıklığını önleyici etkiye sahip olmasından dolayı halk hekimliğinde değerlendirilmektedir. Bu nedenle, gelecekte bu meyveye olan ilginin daha da artacağı belirtilmektedir (Gündoğdu ve ark., 2015).
"Hicaznar çeşidinde farklı uygulamaların soğukta depolama süresince fitokimyasal ve uçucu aroma bileşimine etkileri" adlı çalışmada, narın antioksidan, C vitamini ve niosin bakımından oldukça zengin olduğu, kolesterol ve şeker düzeyini dengelediği, kalp sağlığını koruduğu ve kanser hücrelerinin gelişmesini engellediği belirtilmektedir (Öz ve ark., 2015).

Narın insan sağlığına etkileri konusunda yukarıda açıklanan araştırmaların dışında pek çok araştırıcının da çalışması mevcut olup, bunlardan bazılarının isimleri ve bu çalışmaların yayın yılları aşağıda verilmiştir. Bunlar: 1) Saleh ve ark. (1964), 2) Hartwell (1971), 3) Dokuzoğuz ve Mendilcioğlu (1978), 4) Onur (1988), 5) Yılmaz ve ark. (1992), 6) Anesini ve Perez (1993), 7) Ünal ve ark. (1995), 8) Zhang ve ark. (1995), 9) Mavlyanov ve ark. (1997), 10) Melgarejo ve ark. (2000), 11) Al-Maiman ve Ahmad (2002), 12) Pérez-Vicente ve ark. (2002), 13) Poyrazoğlu ve ark. (2002), 14) Cerda ve ark. (2003), 15) Kazankaya ve ark. (2003), 16) Yang ve Tsao (2003), 17) Maskan (2004), 18) Huetz ve ark. (2005), 19) Kulkarni ve Aradhya (2005), 20) Papoutsi ve ark. (2005), 21) Li ve ark. (2006), 22) Mertens-Talcott ve ark. (2006), 23) Tzulker (2007), 24) Alighourchi ve ark. (2008), 25) Ozgen ve ark. (2008), 26) Tehranifar ve ark. (2010) ve 27) Çalışkan ve Beyazıt (2013). 


\section{Sonuç ve Öneriler}

Ülkemizde 1970'li yıllardan itibaren narın insan sağlığına etkileri konusunda çalışmalar başlamış olup, günümüzde bu araştırmaların sayısı giderek artmıştır. Daha sağııklı bir nesil oluşması için gelecekte bu çalışmalara daha fazla önem verilmesi gerekir.

Ülkemizde nar üretim miktarına kıyasla, nar suyu üretimi oldukça geri kalmıştır. Bunun en önemli nedeni ise endüstriyel işlemeye elverişli nitelikte, miktarda ve fiyatta hammadde temin edilememesidir. Genel olarak, sofralarımızda yeterli miktarda nar suyunu bulundurmak için gerekli miktarda ve uygun fiyatta hammadde temin edilmesi gerekir.

Kanser hücrelerinin gelişimine karşı etkisinin yanı sıra, bazı mantarsal ve bakteriyel mikroorganizmalara karşı antimikrobiyal etki göstermesi nedeniyle, narın hem yaş meyve olarak hem de nar suyu olarak tüketimi yaygınlaştırılmalıdır. Insan sağlığına olan faydalarından dolayı adeta bir ilaç ve hatta antibiyotik olan nar, özellikle bağışıklık sistemini güçlendirdiği ve insanları pek çok hastalıktan koruduğu için, tüketimine özen gösterilmelidir.

İçerdiği bazı maddelerle, insandaki kolesterol ve şekerin dengelenmesine ve kalp sağlığının korunmasına olumlu etkisinden dolayı narın önemi vurgulanmalıdır.

Nar suyunun sadece berrak olarak değil, doğal bulanık meyve suyu olarak da tüketime sunulması durumunda, içeriğindeki değeri yüksek besin bileşenlerinin korunması açısından önemli olan bulanıklık stabilitesinin korunması gerekir. Bu yüzden, bu konu üzerine çalışmaların yaygınlaştırılması gerekir.

Nar çeşit ve genotiplerinde şeker, makro ve mikro besin elementlerinin ve öteki biyokimyasal içeriklerinin tespit edilmesi ve tanıtımlarının yapılması halinde, bu meyve türünün insan sağlığına olan etkilerinden dolayı, bundan sonra yapılacak çalışmalara önemli bir kaynak oluşturacağı kaçınılmazdır.

Narın hem AIDS için kullanılan yiyecekler sınıfına alınması hem de halk hekimliğinde ve günümüz ilaçların hammaddesi arasında yer almasından dolayı, işitsel, görsel ve diğer sosyal medya araçları vasıtasıyla bu meyvenin öneminin vurgulanması ve tüketiminin teşvik edilmesi gerekir.

Geleneksel meyve yetiştiriciliğinden elde edilen ürünlerin insan sağlığı açısından önemi organik meyve yetiştiriciliğine göre daha düşük olmaktadır. Bu nedenle, gerek nar gerekse öteki meyve türlerinin organik yetiştiriciliğine önem verilmesi halinde, elde edilecek ürünün insan sağlığına olumlu etkileri daha da artacaktır.

Sonuç olarak, narın insan sağlığına etkileri konusunda hem ülkemizde hem de nar yetiştiriciliği yapılan öteki ülkelerde pek çok araştırıcı çalışmalarına devam etmektedir. Ayrıca, gelecekte bu konudaki çalışmaların sürdürülebilmesi için araştırmalara yeterli miktarda maddi kaynak sağlanması gerekir. Bu araştırmalardan elde edilecek sonuçların, narın insan sağlığına etkilerinin 
belirlenmesine önemli veriler oluşturacağı, böylece daha sağlıklı bireyler ve toplumların oluşmasına etki edebileceği düşünülmektedir.

\section{Kaynaklar}

Abbasi, H., Rezaei, K., Emamdjomeh, Z., Ebrahimzadeh Mousavi S. M., 2007. Effect of Various Extraction Conditions on the Phenolic Contents of Pomegranate Seed Oil. European Journal of Lipid Science and Technology, 110: 435-440.

Alighourchi, H., Barzegar, M., Abbasi, S., 2008. Anthocyanins Characterization of 15 Iranian Pomegranate (Punica granatum L.) Varieties and Their Variation After Cold Storage and Pasteurization. European Food Research and Technology, 227: 881887.

Al-Maiman, A., Ahmad, D., 2002. Changes in Physical and Chemical Properties During Pomegranate (Punica granatum L.) Fruit Maturation. Food Chemistry, 76: 437-441.

Anesini, C., Perez, C., 1993. Screening of Plants Used in Argentine Folk Medicine for Antimicrobiyal Activity. Journal of Ethonopharmacol, 39: 119-128.

Apaydın, E., 2008. Nar Suyu Konsantresi Üretim ve Depolama Süresince Antioksidan Aktivitedeki Değişimler. Yüksek Lisans Tezi (Basılmamış), Ankara Üniversitesi Fen Bilimleri Enstitüsü, Ankara.

Aviram, M., Dornfeld, L., Rosenblat, M., Volkona N., Kaplan, M., Coleman, R., Hayek, T., Presser, D., Fuhrman, B., 2000. Pomegranate Juice Consumption Reduces Oxidative Stress, Atherogenic Modifications to LLD, and Platelet Aggregation: Studies in Humans and in Atherosclerotic Apolipoprotein EDeficientmice. The American Journal of Clinical Nutrition, 71: 1062-1076.

Caliskan, O., Bayazit, S., 2013. Morphopomological and Chemical Diversity of Pomegranate Accessions Grown in Eastern Mediterranean Region of Turkey. Journal of Agricultural Science and Technology, 15: 1449-1460.

Cemeroğlu, B., 1977. Nar Suyu Üretim Teknolojisi Üzerinde Araştırmalar. Ankara Üniversitesi
Ziraat Fakültesi Yayınları, No: 664, Ankara, $71 \mathrm{~s}$

Cemeroğlu, B., 2009. Meyve ve Sebze İşleme Teknolojisi. 1. Cilt. Kültür ve Turizm Bakanlığı Yayınları, Ankara, $480 \mathrm{~s}$.

Cerda, B., Llorach, R., Ceron, J. J., Espin, J. C., Tomas-Barberan, F. A., 2003. Evaluation of the Bioavailability and Metabolism in the Rat of Punicalagin, an Antioxidant Polyphenol from Pomegranate Juice. European Journal of Nutrition, 42: 18-28.

Coşkun, F., 2006. Gıdalarda Bulunan Doğal Koruyucular. Gıda Teknolojileri Elektronik Dergisi, 2: 27-33.

Dokuzoğuz, M., Mendilcioğlu, K., 1978. Ege Bölgesi Nar Çeşitleri Üzerinde Pomolojik Çalışmalar. Ege üniversitesi Ziraat Fakültesi Dergisi, 15: 133-157.

Duman, A. D., Ozgen, M., Dayisoylu, K. S., Erbil, N., Durgac, C., 2009. Antimicrobial Activity of Six Pomegranate (Punica granatum L.) Varieties and Their Relation to Some of Their Pomological and Phytonutrient Characteristics. Molecules, 14(5): 18081817.

Durgac, C., Özgen, M., Şimşek, Ö., Kaçar, Y. A., Kıyga, Y., Çelebi, S., Gündüz, K., Serçe, S., 2008. Molecular and Pomological Diversity Among Pomegranate (Punica granatum L.) Cultivars in Eastern Mediterranean Region of Turkey. African Journal of Biotechnology, 7(9): 1294-1301.

Ekşi, A., Ozhamamci, I., 2009. Chemical Composition and Guide Values of Pomegranate Juice. Gıda, 34: 265-270.

Fischer, U, A., Carle, R., Kammerer, D. R., 2011. Identification and Quantification of Phenolic Compounds from Pomegranate (Punica granatum L.) Peel, Mesocarp, Aril and Differently Produced Juices by HPLCDAD-ESI/MSn. Food Chemistry, 127: 807821.

Gerçekçioğlu, R., Bilgener, ş., Soylu, A., 2014. Genel Meyvecilik (Meyve Yetiştiriciliğinin Esasları). NOBEL Akademik Yayıncılık, Geliştirilmiş 4. Basım, İstanbul, $498 \mathrm{~s}$.

Gil, M. I., Tomas-Barberan, F. A., Hess-Pierce, B., Holcroft, D. M., Kader, A. A., 2000. Antioxidant Activity of Pomegranate Juice and Its Relationship with Phenolic Composition and Processing. Journal of Agricultural and Food Chemistry, 48: 45814589. 
Gündoğdu, M., Yılmaz, H., Şensoy, R. I. G., Gündoğdu, Ö., 2010. Şirvan (Siirt) Yöresinde Yetiştirilen Narların Pomolojik Özellikleri. Yüzüncü Yıl Üniversitesi Tarım Bilimleri Dergisi, 20: 138-143.

Gündoğdu, M., Yılmaz, H., 2013. Bazı Standart Nar (Punica granatum L.) Çeşitleri ve Genotiplerine Ait Meyvelerin C Vitamini, Şeker ve Besin Elementleri İçeriklerinin Belirlenmesi. Yüzüncü Yıl Üniversitesi Tarım Bilimleri Dergisi, 23: 242-248.

Gündoğdu, M., Yılmaz, H., Canan, İ., 2015. Nar (Punica granatum L.) Çeşit ve Genotiplerin Fizikokimyasal Karakterizasyonu. Uluslararası Tarım ve Yaban Hayatı Bilimleri Dergisi, 1: 57-65.

Hartwell, J., 1971. Plants Used Against Cancer. Lloydia, 34: 105-107.

Huertz, P., Mavaddat, N., Mavri, J., 2005. Reaction Between Ellagic Acid and An Ultimate Carcinogen. Journal of Chemical Information and Modeling, 45: 1564-1570.

İkinci, A., Kılıç, M.E., 2016. Siverek (Şanlıurfa) Yöresinde Yetiştirilen Yerel Nar (Punica granatum L.) Genotiplerinin Bazı Pomolojik ve Kimyasal Özellikleri. Yüzüncü Yıl Üniversitesi Tarım Bilimleri Dergisi, 26 (4): 556-562.

Karaca, E., 2011. Nar Suyu Konsantresi Üretiminde Uygulanan Bazı İşlemlerin Fenolik Bileşenler Üzerine Etkisi. Yüksek Lisans Tezi (Basılmamış). Çukurova Üniversitesi Fen Bilimleri Enstitüsü, Adana.

Kazankaya, A., Gündoğdu, M., Aşkın, M. A., Muradoğlu, F., 2003. Pervari (Siirt) Narlarının Meyve Özellikleri. IV. Ulusal Bahçe Bitkileri Kongresi. Akdeniz Üniversitesi Ziraat Fakültesi, 08-12 Eylül 2003, Antalya, s.141-143.

Kelebek, H., Canbaş, A., 2010. Hicaznar Şırasının Organik Asit, Şeker ve Fenol Bileşikleri İçeriği ve Antioksidan Kapasitesi. Gıda, 35: 439-444.

Kulkarni, A. P., Aradhya, S. M., 2005. Chemical Changes and Antioxidant Activity in Pomegranate Arils During Fruit Development. Food Chemistry, 93: 319324.

Kurt, H., Şahin, G., 2013. Bir Ziraat Coğrafyası Çalışması: Türkiye'de Nar (Punica granatum L.) Tarımı. Marmara Coğrafya Dergisi, 27: 551-574.

Li, Y., Guo, C., Yang, J., Wel, J., Xu, J., Cheng, S., 2006. Evaluation of Antioxidant Properties of Pomegranate Peel Extract in
Comparison with Pomegranate Pulp Extract. Food Chemistry, 96: 254-260.

Lansky, E., Shubert, S., Neeman, I., 2000. Pharmacological and Therapeutic Properties of Pomegranate. In: MelgarejoMoreno, P., Martínez-Nicolás, J. J., Martínez-Tomé, J. (eds.). Production, Processing and Marketing of Pomegranate in the Mediterranean Region: Advances in Research and Technology. Zaragoza: CIHEAM-IAMZ, p. 231-235.

Malik, A., Afaq, F., Sarfaraz, S., Madhami, V., Syed, D., Mukhtar, H., 2005. Pomegranate Fruit Juice for Chemoprevention and Chemotherapy of Prostate Cancer. Proceedings of the National Academy of Sciences USA, 102: 14813-14818.

Mars, M., Marakchi, M., 1999. Diversity of Pomegranate (Punica granatum L.) Germplasm in Tunisia. Genetic Research Crop Evolation, 46: 461-467.

Maskan, M., 2004. Production of Pomegranate (Punica granatum L.) Juice Concentrate by Various Heating Methods: Colour Degradation and Kinetics. Journal of Food Engineering, 72: 218-224.

Mavlyanov, S. M., Islambekov, S. Y., Karimdzhanov, A. K., Ismailov, A. I., 1997. Polyphenols of Pomegranate Peels Show Marked Antitumor and Antiviral Action. Khim Prir Soedin, 33: 124-126.

Melgarejo, P., Hernadez, F., Martinez, J., TomasBarberan, F. A., Artes, F., 2000. Evolution of Pomegranate Juice Anthocyanins During the Ripening of Fruit of Three Clones: ME16, VA1, BA1. Zaragoza. CIHEAM-IAMZ, 253: 123-127.

Mertens-Talcott, S. U., Jilma-Stohlawetz, P., Rios, J., Hingorani, L., Derendorf, H., 2006. Absorption, Metabolism, and Antioxidant Effects of Pomegranate (Punica granatum L.) Polyphenols After Ingestion of a Standardized Extract in Healthy Human Volunteers. Journal of Agricultural and Food Chemistry, 54: 8956 -8961.

Oğuz, H. İ., Ukav, ì., Eroğlu, D., 2011. Güneydoğu Anadolu Bölgesi'nde Nar (Punica granatum L.) Üretimi ve Pazarlanması. GAP VI. Tarım Kongresi, 09-12 Mayıs 2011, Şanlıurfa, s. 108-112.

Onur, C., 1988. Nar. Derim, 5: 176-178.

Ozgen, M., Durgac, C., Serce, S., Kaya, C., 2008. Chemical and Antioxidant Properties of Pomegranate Cultivars Grown in 
Mediterranean Region of Turkey. Food Chemistry, 111: 703-706.

Öz, A. T., Kafkas, E., Zarifikhosroshahi, M., Şahin, T., 2015. 'Hicaznar' Çeşidinde Farklı Uygulamaların Soğukta Depolama Süresince Fitokimyasal ve Uçucu Aroma Bileşimine Etkileri. Türk Tarım-Gıda Bilim ve Teknoloji Dergisi, 3: 235-241.

Özgüven, A. I., Yılmaz, C., 2000. Pomegranate Growing in Turkey. In: Melgarejo-Moreno, P., Martínez-Nicolás, J. J., Martínez-Tomé, J. (eds.). Production, Processing and Marketing of Pomegranate in the Mediterranean Region: Advances in Research and Technology. Zaragoza: CIHEAM-IAMZ, p. 41-48.

Özkal, N., Dinç, S., 1993. Nar (Punica granatum L.) Meyva Kabuklarının Eczacılık Yönünden Değerlendirilmesi. Ankara Eczacılık Fakültesi Dergisi, 22: 1-2.

Papoutsi, Z., Kassi, E., Tsiapara, A., Fokialakis, N., Chrousos, G. P., Moutsatsou, P., 2005. Evaluation of Estrogenic/Antiestrogenic Activity of Ellagic Acid via the Estrogen Receptor Subtypes ER $\alpha$ and ER $\beta$. Journal of Agricultural and Food Chemistry, 53: 7715-7720.

Pérez-Vicente, A., Gil-Izqierdo, A., Garcia-Viguera, C., 2002. In vitro Gastrointestinal Digestion Study of Pomegranate Juice Phenolic Compounds, Anthocyanins and Vitamin C. Journal of Agricultural and Food Chemistry, 50: 2308-2312.

Poyrazoğlu, E., Gökmen, V., Artk, N., 2002. Organic Acids and Phenolic Compounds in Pomegranates (Punica granatum

Üniversitesi Fen Bilimleri Enstitüsü Dergisi, 7(2): 131-141.

Tamer, C. E., 2006. Nar: Bileşimi ve İnsan Sağlığı Üzerindeki Etkileri. Gıda ve Yem BilimiTeknolojisi, 9: 1-7.

Tehranifar, A., Zarel, M., Nemati, Z., Esfandiyari, B., Vasifeshenas, M. R., 2010. Investigation of Physico Chemical Properties and Antioxidant Activity of Twenty Iranian Pomegranate (Punica granatum L.) Cultivars. Scientia Horticulturae, 126: 180185.

Tezcan, F., Gültekin-Özgüven, M., Diken, T., Özçelik, B., Erim, F. B., 2009. Antioxidant Activity and Total Phenolic, Organic Acid and Sugar Content in Commercial Pomegranate Juices. Food Chemistry, 115: 873-877.
Grown in Turkey. Journal of Food Composition and Analysis, 15: 567-575.

Priyadarsini, K, I., Khopde, S. M., Kumar, S .S., Mohan, H., 2002. Free Radical Studies of Ellagic Acid, A Natural Phenolic Antioxidant. Journal of Agricultural and Food Chemistry, 50: 2200-2206.

Saleh, M. A., Amer, M. K. M., Radwan, A. E. W., Amer, M. E. S., 1964. Experiments on Pomegranate Seeds and Juice Preservation. Agricultural Research Review, 42: 54-64.

Singh, M., Arseneault, M., Sanderson, T., Morthy, V., Ramassamy, C., 2008. Challenges for Research on Polyphenols from Foods in Alzheimer's Disease: Bioavailability, Metabolism and Cellular and Molecular Mechanism. Journal of Agriculture and Food Chemistry, 56: 4855-4873.

Şimşek, M., Gülsoy, E., 2016. Ceviz ve İçerdiği Yağ Asitlerinin İnsan Sağlığı Açısından Önemi Üzerine Yapılan Bazı Çalışmalar. Iğdır Üniversitesi Fen Bilimleri Enstitüsü Dergisi, 6: 9-15.

Şimşek, M., Kara, A., 2016. Diyarbakır Meyvecilik Potansiyeline Genel Bir Bakış. Basımda. Uluslararası Diyarbakır Sempozyumu, 2-5 Kasım 2016, Diyarbakır.

Şimşek, M., Yücel, B., 2015. Çevre Dostu Meyve Üretim Tekniği Açısından Güneydoğu Anadolu Bölgesi. Güneydoğu Anadolu Bölgesi Çevre Sorunları Sempozyumu ve Çalıştayı, 24-25 Mart 2015, Diyarbakır, s. 227-234.

Şimşek, M., Gülsoy, E., 2017. Güneydoğu Anadolu Bölgesinin Nar (Punica granatum L.) Potansiyeli Konusunda Bir Araştırma. Iğdır

Turgut, D. Y., Seydim, A. C., 2013. Akdeniz Bölgesi'nde Yetiştirilen Bazı Nar (Punica granatum L.) Çeşit ve Genotiplerinin Fenolik Bileşenleri ve Antioksidan Aktivitelerinin Belirlenmesi. Akademik Gıda, 11: 51-59.

TÜiK, 2015. Türkiye İstatistik Kurumu (TÜiK). http://www.tuik.gov.tr/bitkiselapp/bitkisel .zul (Erişim: 21.05.2017).

Tzulker, R., Glazer, I., Bar-llan, I., Holland, D., Aviram, M., Amir, R., 2007. Antioxidant Activity, Polyphenol Content, and Related Compounds in Different Fruit Juices and Homogenates Prepared from 29 Different Pomegranate Accessions. Journal of Agricultural and Food Chemistry, 55: 9559-9570. 
Ünal, Ç., Velioğlu, S., Cemeroğlu, B., 1995. Türk Nar Sularının Bileşim Öğeleri. Gıda, 20: 339-345.

Vardin, H., 2000. Harran Ovası'nda Yetişen Değişik Nar Çeşitlerinin Gıda Sanayinde Kullanım Olanakları Üzerine Bir Çalışma. Doktora Tezi (Basılmamış). Çukurova Üniversitesi Fen Bilimleri Enstitüsü, Adana.

Yang, R., Tsao, R., 2003. Optimization of A New Mobile to Know the Complex and Real Polyphenolic Composition: Towards A Tool Phenolic Index Using High Performance
Liquid Chromatography. Journal of Chromatogr A, 1018: 29-40.

Yılmaz, H., Şen, B., Yıldız, A., 1992. Akdeniz Bölgesi'nde Seçilen Narların Bölgesel Adaptasyonu. Türkiye I. Ulusal Bahçe Bitkileri Kongresi. 13-16 Ekim 1992, İzmir, s. 449-452.

Zhang, J., Zhan, B., Yao, X., Gao, Y., Shong, J., 1995. Antiviral Activity of Tannin from the Pericarp of Punica granatum L. Against Genital Herpes Virus in Vitro. China Journal of Chinese Materia Medica, 20(9): 556-558 